\title{
Hurricane impacts on a pair of coastal forested watersheds: implications of selective hurricane damage to forest structure and streamflow dynamics
}

\author{
A. D. Jayakaran ${ }^{1}$, T. M. Williams ${ }^{1}$, H. Ssegane ${ }^{2}$, D. M. Amatya ${ }^{3}$, B. Song ${ }^{1}$, and C. C. Trettin ${ }^{3}$ \\ ${ }^{1}$ The Baruch Institute of Coastal Ecology and Forest Science, Clemson University, Georgetown, SC, USA \\ ${ }^{2}$ Energy Systems Division, Argonne National Laboratory, Argonne, IL, USA \\ ${ }^{3}$ Center for Forested Wetlands Research, USDA Forest Service, Cordesville, SC, USA
}

Correspondence to: A. D. Jayakaran (ajayaka@clemson.edu)

Received: 13 August 2013 - Published in Hydrol. Earth Syst. Sci. Discuss.: 12 September 2013 Revised: 2 February 2014 - Accepted: 12 February 2014 - Published: 26 March 2014

\begin{abstract}
Hurricanes are infrequent but influential disruptors of ecosystem processes in the southeastern Atlantic and Gulf coasts. Every southeastern forested wetland has the potential to be struck by a tropical cyclone. We examined the impact of Hurricane Hugo on two paired coastal South Carolina watersheds in terms of streamflow and vegetation dynamics, both before and after the hurricane's passage in 1989. The study objectives were to quantify the magnitude and timing of changes including a reversal in relative streamflow difference between two paired watersheds, and to examine the selective impacts of a hurricane on the vegetative composition of the forest. We related these impacts to their potential contribution to change watershed hydrology through altered evapotranspiration processes. Using over 30 years of monthly rainfall and streamflow data we showed that there was a significant transformation in the hydrologic character of the two watersheds - a transformation that occurred soon after the hurricane's passage. We linked the change in the rainfall-runoff relationship to a catastrophic change in forest vegetation due to selective hurricane damage. While both watersheds were located in the path of the hurricane, extant forest structure varied between the two watersheds as a function of experimental forest management techniques on the treatment watershed. We showed that the primary damage was to older pines, and to some extent larger hardwood trees. We believe that lowered vegetative water use impacted both watersheds with increased outflows on both watersheds due to loss of trees following hurricane impact. However, one
\end{abstract}

watershed was able to recover to pre hurricane levels of evapotranspiration at a quicker rate due to the greater abundance of pine seedlings and saplings in that watershed.

\section{Introduction}

Runoff generation is a poorly understood phenomenon in low-gradient forested wetland watersheds found on the southeastern Gulf and Atlantic coastal plains, where soil saturation may occur over the entire watershed. Storm runoff varies widely, from none to over $70 \%$ of rainfall (Epps et al., 2013), which is believed to be related to soil water and depression storage. In low-gradient forested watersheds, we anticipate an even greater coupling of transpirative and soil water dynamics in runoff generation processes (Amatya et al., 1996; Slattery et al., 2006; Sun et al., 2010; Amatya and Skaggs, 2011; Dai et al., 2011; Skaggs et al., 2011; Tian et al., 2012). Using isotope effects of transpiration and evaporation from a global data set, Jasechko et al. (2013) demonstrated that transpiration is the major component of the total evapotranspiration (ET) process in the global water cycle. In lowgradient forested watersheds in the southeastern USA, Dai et al. (2013) showed that ET accounted for about $76 \%$ of precipitation loss from a coastal forested watershed while Sun et al. (2010) suggested a range of 70-113\% from a managed pine plantation. Using sap-flux measurements from a small high-gradient watershed (mean slope $57 \%$ ) with a closed 
evergreen canopy and thick litter layer, Ford et al. (2007) demonstrated that 56 and $60 \%$ of incident precipitation for 2004 and 2005 could be accounted for by ET, respectively. A similar study by Wilson et al. (2006) in a medium-gradient, well-drained watershed compared multiple methods for determining forest ET. Based on Ford et al. (2007) and Wilson et al. (2006), reported transpiration losses ranged between 53 and $57 \%$ of ET, with the balance comprising canopy interception and direct soil evaporation. Using eddy flux tower measurements, Domec et al. (2012) showed that transpiration accounted for $70 \%$ of total ET in a mid-rotation managed pine forest. Similarly, Sun et al. (2010) showed that transpiration and soil evaporation accounted for about $83 \%$ of total ET. In forested watersheds dominated by closed canopies and thick litter layers, soil evaporation is likely to be minimal (e.g., Ford et al., 2007), though Domec et al. (2012) report a value of $9 \%$ of ET attributed to soil evaporation from a mid-rotation managed pine plantation. Interception losses or canopy evaporation losses are closely linked to forest structure - Bryant et al. (2005) reported interception losses equivalent to 17.7 and $18.6 \%$ of total precipitation for a mixed forest and lowland hardwood forest, respectively. A simulation study on a low-gradient coastal forested watershed by Tian et al. (2012) reported that canopy interception accounted for $16 \%$ of ET. Amatya et al. (1996) reported a value of $24 \%$ while Sun et al. (2010) reported an average interception loss of $15 \%$ of incident precipitation - both studies were carried out in intensively managed pine plantations. In every case, the impact of interception and transpiration losses suggests the dominant effect of evapotranspiration on the hydrologic budget of forested watersheds. Given the close coupling of forest structure and hydrology that is likely to be amplified by the low gradients characterizing southeastern coastal plains, understanding runoff generation is critical where disruptors to forest structure can occur suddenly (hurricanes) or over longer time periods (climate change) (Dai et al., 2011, 2013).

Much of our understanding of runoff generation from forested lands has come from paired watershed experiments conducted over the last century (Hewlett et al., 1969; Andreassian, 2004; Ice and Stednick, 2004; Ssegane et al., 2013; Zon, 1927). The paired watershed approach has been used in forest hydrology research in the USA for over 100 years to examine impacts of silvicultural treatments and watershed disturbances on watershed outflows. With this technique, flows from two closely matched watersheds are measured over several years to establish paired relationships over a range of climatic variability (Hewlett, 1982). After developing a statistically significant calibration relationship between the watersheds, an experimental treatment can be imposed on one watershed, while the other is used as a control. The covariance of streamflows between the pair with variation in climate creates a powerful statistical test allowing for significance testing of even small treatment effects (Wicht, 1967).

The paired watershed technique has faced some criticism over the years (Peel, 2009; Vogl and Lopes, 2010). Criti- cisms have included cost, leakiness, lack of representation, sensitivity to change, transference of results, and confounding of multiple processes (see review by Hewlett et al., 1969). The technique also cannot differentiate between water loss by transpiration (controlled by vegetation) and evaporation from wet surfaces including canopy surfaces. Transpiration losses have been shown to influence soil water and thereby indirectly affect runoff generation processes (Johnston, 1970; Klock and Helvey, 1976) and annual water yields (Megahan, 1983; Troendle and King, 1985; Watson et al., 1999; Sun et al., 2005). In this study we illustrate a shortcoming of the paired watershed technique - that adjacent watersheds sometimes respond differently to climate forcings or extreme events such as hurricanes - and a strength of the technique that retrospective analyses of long-term data sets from experimental watersheds are critical to understanding subtle ecosystem controls on hydrologic processes.

Hurricanes are infrequent but influential disruptors of ecosystem processes in the southeastern Atlantic and Gulf coasts. The ecological impact of tropical cyclones has been widely studied leading to several summaries of recent majorhurricane impacts (e.g., Bokaw and Walker, 1991; Haymond and Harms, 1996; Stanturf et al., 2007; Kupfer et al., 2008). Lugo's (2008) analysis of hurricane-force tropical cyclones presents an interesting description of hurricane effects as visible and invisible. Visible effects are the commonly described impact of high winds and heavy rainfall summarized by Everham and Brokaw (1996). Invisible effects alter the forest structure and species composition and may result in development of certain ecosystem characteristics, increases in vines, short trees, and dense continuous crowns (Lugo, 2008).

The impact of a severe hurricane and subsequent revegetation dynamics on runoff from a pair of watersheds on the southeastern Atlantic coast is an "invisible" effect described by this study. This study seeks to characterize an apparent anomalous reversal in relative flow pattern/magnitude between two paired watersheds in the Santee Experimental Forest (SEF) on the coast of South Carolina (SC) first reported in Amatya et al. (2006). The reversal in relative flow magnitudes appears to be influenced by the impact of Hurricane Hugo on 22 September 1989, described by Hook et al. (1991). During the initial calibration period that followed outlet instrumentation, the control watershed consistently produced less runoff than its pair (Williams et al., 2012). A few years after Hugo, the same watershed began to produce greater runoff, a condition that persisted for over a decade. Recently however, the relationship between the two watersheds has reverted to its original state observed prior to Hugo. The three eras describing the relative flow differences between the watersheds: historical era, reversal in relative flow difference, and return to original conditions are henceforth referred to as pre, flip, and flop eras, respectively. While the nomenclature for the three eras may suggest sudden changes in streamflow production, the actual transitions between the eras occurred gradually over several years. 


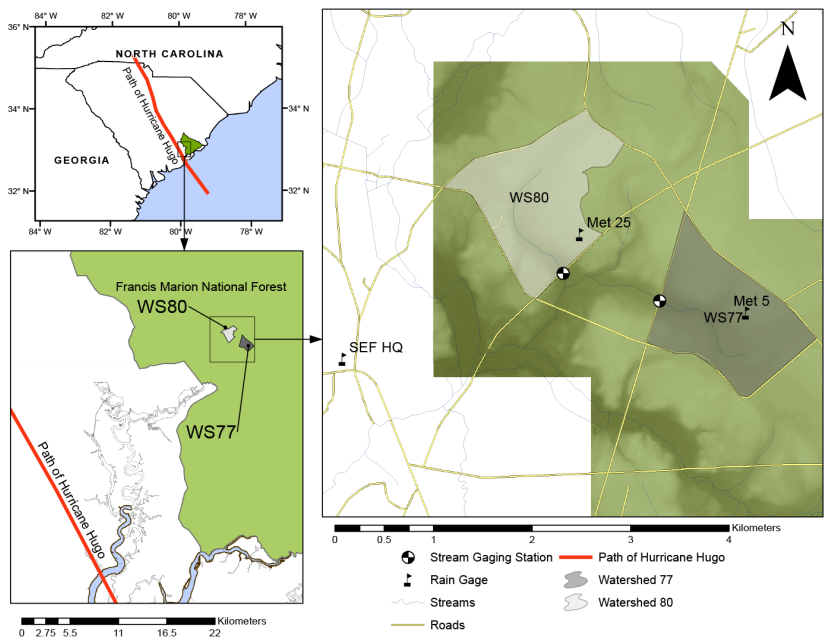

Fig. 1. Location of watersheds 77 and 80 in the Santee Experimental Forest within the Francis Marion National Forest on the South Carolina coast in relation to the path of the eye of Hurricane Hugo, September 1989.

Both Amatya et al. (2006) and Williams et al. (2012) provide additional details and first-order statistics related to the relative changes in flow magnitudes between the two watersheds. For this study, we have chosen to focus on the use of moving-window-type temporal analyses of streamflow data to capture decadal-long hydrologic processes. In particular, the study objectives are (1) to quantify the magnitude and timing of changes including a reversal in relative streamflow magnitude between paired watersheds associated with a catastrophic climatic event (Hurricane Hugo in 1989), and (2) to examine selective impacts of a hurricane on vegetative composition and its potential effect on streamflow through altered evapotranspiration processes.

\section{Methods}

\subsection{Study site}

The watersheds of interest are located at $33.15^{\circ} \mathrm{N}, 79.8^{\circ} \mathrm{W}$ within the SEF, a part of the USDA Forest Service's Francis Marion National Forest (Fig. 1). Over the last half-century, the forest has been intensively studied with over 190 shortand long-term vegetation studies. The forest is also the site of one of the first paired watershed studies on wetland-forested watersheds in the USA (USDAFS, 1963; Amatya and Trettin, 2007). Common soils in the area are aquic alfisols or ultisols, which typically contain argillic horizons (SCS, 1980). These topographic and soil characteristics indicate a high surface water detention capacity and slow surface water drainage. The climate is mild and wet, with an average temperature of $18.3^{\circ} \mathrm{C}$, and an average annual precipitation of $1370 \mathrm{~mm}$ (Dai et al., 2013; Harder et al., 2007).
In the mid 1960s, two similar first-order watersheds in SEF, watershed 77 (WS77) and watershed 80 (WS80) were selected to characterize hydrologic processes in low-gradient forested wetland watersheds using the classical pairedwatershed approach (Young and Klawitter, 1968). WS77, the treatment watershed, was instrumented in November 1963 and was 155 ha in size; WS80, the control watershed, was instrumented in November 1968 and was 206 ha in drainage area. In November 2001, a small section of WS80 was allowed to drain separately through a small culvert reducing its drainage area to 160 ha. WS77 has experienced several silvicultural treatments carried out over the past 40 years (e.g., Gillham, 1984; Richter et al., 1983, 1982; Binstock, 1978; Amatya et al., 2006).

In September 1989, Hurricane Hugo struck the South Carolina Coast with wind speeds of $60 \mathrm{~m} \mathrm{~s}^{-1}$ (Sparks, 1991), its eye passing through the Francis Marion National Forest (Fig. 1). The Santee Experimental Forest, located $40 \mathrm{~km}$ from the coast, was in close proximity to the path taken by the storm's eye and received severe damage. After the passage of the storm, there were less than $20 \%$ of pines and hardwoods still left standing in the forest (Hook et al., 1991). High wind speeds were sustained as the storm progressed inland - wind speeds of $49 \mathrm{~m} \mathrm{~s}^{-1}$ were measured in Sumter, SC, $139 \mathrm{~km}$ from the coast, (Brennen, 1991). Soon after Hurricane Hugo, WS77 underwent a salvage harvest, where high-valued damaged or fallen trees were removed from the watershed WS80 however was left untouched. Additional descriptions of the site, field measurements and past studies are detailed in Dai et al. (2013), Harder et al. (2007), Amatya et al. (2006), Amatya and Trettin (2007), and Amatya and Radecki-Pawlik (2007).

\subsection{Hydrologic monitoring}

For the period between 1969 and 1996, rainfall was measured in WS77 on a daily basis using a weighing-bucket-type rain gauge (Met5 in Fig. 1). In 1990, another weighing-buckettype rain gage was installed in WS80 (Met25 in Fig. 1). In 1996, weighing-bucket-type rain gages in both watersheds were replaced with automatic tipping-bucket rain gauges. However due to a variety of reasons, concurrent daily rainfall readings in both watersheds were only available for the periods 1990-1997, 2001-2008, and 2010-2011. There is a continuous record of rainfall for the entire 1969-2011 period recorded at the SEF headquarters rain gauge (SEF HQ in Fig. 1). Amatya et al. (2006) also examined spatial variability of historic 1964-1982 rainfall data from five randomly spread gages in SEF and concluded that the average coefficient of variation among gages was just $3 \%$. We analyzed concurrently available daily rainfall data for similarity of rainfall totals measured within the two study watersheds using a three-way between groups analysis of variation (ANOVA) test. 
Continuous flow records from these watersheds were collected from 1964 through 1981 (Amatya et al., 2006; Richter et al., 1982, 1983; Binstock, 1978; Young and Klawitter, 1968; Young et al., 1972). WS77 and WS80 were calibrated using streamflow data between 1969 and 1976, followed by a series of prescribed burning experiments on WS77 from 1977 through 1981 (Richter et al., 1982, 1983). Data collection resumed in November 1989, following Hugo, and has continued until the present (Amatya et al., 2003, 2006; Miwa et al., 2003; Sun et al., 2000; Harder et al., 2007; Dai et al., 2013). Streamflow rates on both watersheds (WS77 and WS80) were estimated using a compound weir instrumented with stage recorders. All stage data until 1995 were recorded on magnetic tapes using analog-digital recorders that were digitized at the USDA Forest Service's Coweeta Hydrologic Laboratory (Amatya et al., 2006; Williams et al., 2012). Data on the daily stream outflow measured between 19691981 and 1990-2011 (http://www.srs.fs.usda.gov/charleston/ santee/data.html; Dai et al., 2013) were analyzed for this study. Daily data were summed on a monthly basis, as were differences in flow between the two watersheds.

Infiltration losses for this study were considered to be minimal based on Harder et al. (2007), who reported that deep seepage or infiltration losses are negligible in coastal forest systems. Additionally, recent work by Callahan et al. (2012) on a proximal but larger watershed yielded about 5-10\% of annual precipitation lost to groundwater for a moderately well drained upland site. Since both watersheds in the current study comprise poorly drained soils and are almost 35 times smaller in drainage area than the one studied by Callahan et al. (2012), we anticipated even lower groundwater recharge possibly in the order of $2-3 \%$ of incident precipitation. Assuming that direct soil evaporation is negligible under a closed forest canopy, and interception losses are in the order of about $17 \%$, we assume that the balance of almost $80 \%$ of ET is attributable to transpiration losses.

\subsection{Characterizing flows in WS77 and WS80}

Total monthly flow differences between the watersheds expressed as a unit depth of runoff were evaluated for the entire period of record. The flow data covered the period before (1969-1981) and after Hurricane Hugo (1990-2011) with missing data for the periods 1982-1989 and 1999-2002 due to lapses in watershed monitoring. Some missing monthly data from 1995 were estimated using multivariate adaptive regression splines (Adamowski et al., 2012; Balshi et al., 2009; Friedman, 1991) where monthly rainfall was used as an explanatory variable. Local polynomial regression fitting (LOESS) techniques (Cleveland and Grosse, 1991) were used with monthly flow difference data to create smoothed trend lines that helped to discern the deterministic component of data variation with time. The LOESS technique is governed solely by the distribution of the data in bivariate space. The degree to which smoothing takes place is con- trolled by a "bandwidth" parameter that defines the neighborhood of data points used to fit a polynomial function - the greater the bandwidth, the smoother the fitted LEOSS regression. LOESS bandwidth was chosen based on an improved Aikaike information criterion (Aikaike, 1973) proposed by Hurvich et al. (1998). Parameter selection for polynomial functions using the Aikaike information criterion (AIC) typically involve large sample numbers. The improved AIC criterion for smoothing parameter selection corrects for small sample bias and consequent model overfitting that affects standard AIC and generalized cross validation procedures (Hurvich et al., 1998). We carried out all statistical analyses using the R statistical software (version 2.15.2) (RCoreTeam, 2012).

\subsection{Structural changes in monthly rainfall-streamflow relationships}

Changes in the long-term behavior of time series can be identified by change detection techniques such as cumulative or moving sums of recursive residuals - CUSUM or MOSUM (Brown et al., 1975; Bauer and Hackl, 1978; Chu et al., 1995). The null hypothesis tested by both CUSUM and MOSUM is that regression coefficients of a linear model are constant over time; the alternative hypothesis is that the coefficients change over time due to influence of an external factor. Both methods have been used for change detection in eco-hydrology (de Jong et al., 2012; Verbesselt et al., 2010; Vogl and Lopes, 2010; Webb et al., 2012; de Jong et al., 2013; Verbesselt et al., 2012; Tsutsumida et al., 2013; Forkel et al., 2013), economic analysis (Caporale et al., 2011; Ghosh, 2009; Olmo et al., 2011; Tiwari et al., 2012) and quality control (Saghaei et al., 2009). However, CUSUM is considered to be less sensitive to certain changes in regression coefficients especially if the changes occur in the later dates of the period under consideration (Bauer and Hackl, 1978; Chu et al., 1995). MOSUM is more sensitive to parameters that are temporary unstable because the cumulated sums become less sensitive as the number of residuals becomes larger. Therefore, for this study we chose MOSUM to detect significant changes in runoff response.

The MOSUM test was implemented in R using the "strucchange" package (Zeileis et al., 2012) to determine which watershed's (WS77 or WS80) hydrologic regime shifted due to Hurricane Hugo and thus changed the historical hydrologic relationship between watersheds. Linear regression models were independently fitted for WS77 and WS80 using monthly streamflow as the response variable, and the monthly rainfall as the explanatory variable. A window size of 12 months was used to detect structural changes in the regression coefficients. Use of a moving window size of 6 and 24 months did not significantly $(\alpha=0.05)$ affect the estimated change point dates. Although the window size $(w)$ is mainly a smoothing parameter, it also sets the minimum span between two subsequent break points - therefore window 


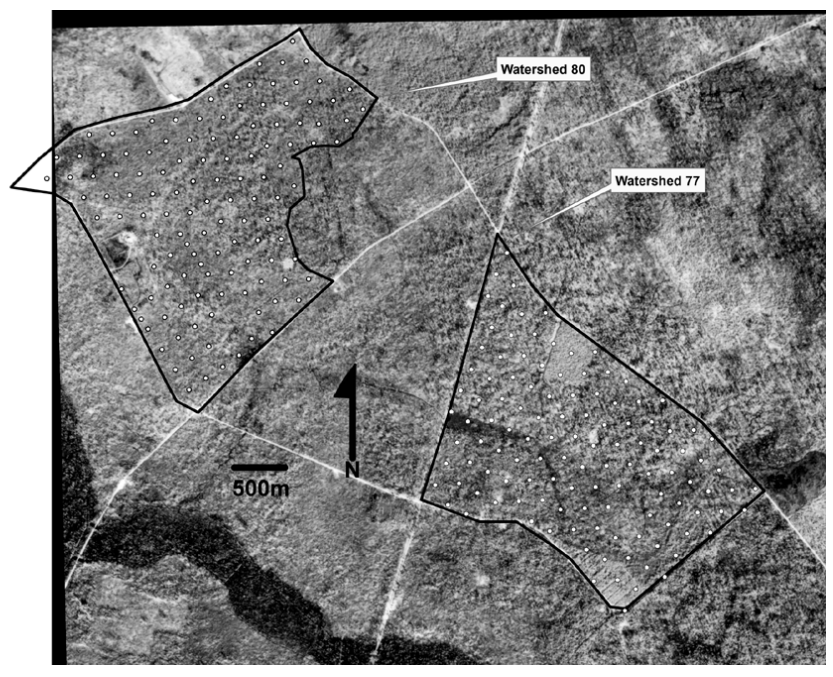

Fig. 2. Locations of vegetation sampling plots placed on watersheds 77 and 80 in 1991 and summarized in this paper.

size has to be chosen with caution. The MOSUM test for change detection follows a three-step procedure. The first step checks for existence of structural change based on the assumption that the variability of the moving sums of recursive residuals under structural stability follows a Brownian motion (a random walk) with an expected mean of zero. If the MOSUM crosses the $95 \%$ confidence boundary, then structural change is detected. For details on the technical basis and the asymptotic function of the $95 \%$ confidence boundary, readers are referred to Zeileis et al. (2012). When structural change is detected in the first step, then steps two and three determine the number and location of the change points (break points or break dates). The break points and corresponding $95 \%$ confidence intervals are estimated based on methods developed by Bai $(1994,1997)$ and Bai and Perron (1998), and implemented by Zeileis et al. (2012). The second step determines the number of break points by minimizing the Bayesian information criterion. However, one can predefine the maximum number of breakpoints for a given time series. For this analysis, this number was set to three to account for pre, flip and flop periods. The third step iteratively determines the location of the break points by minimizing the regression sum of squares.

Based on the above procedural implementation of MOSUM and the fact that the analysis is made on moving sums, the location where the MOSUM crosses the $95 \%$ confidence boundary is not always the location of the breakpoints. Additionally, when the MOSUM returns within the confidence boundaries it does not mean the relationship has regained the structural stability. Finally, the strength of the linear relationship, the size of the moving window, and the number of predetermined breakpoints influence the location of the breakpoints.

\subsection{Measuring vegetation response}

Agents of the Forest Service's Southern Research Station initiated a sampling study in the SEF to quantify the initial damage and subsequent recovery of the forest structure due to Hugo. Unfortunately, only initial plot measurements were made in 1991 and those data were lost in subsequent technology transfers. However, we were able to locate paper copies of the original field data that we used to generate digital information for 169 plots on WS80 and 119 plots on WS77. The one-tenth acre $\left(395 \mathrm{~m}^{2}\right)$ circular plots were laid out on approximately a 10 chain $(201 \mathrm{~m}) \times 6$ chains $(121 \mathrm{~m})$ grid (Fig. 2). Every tree in a one-tenth acre circular plot was tallied by species, diameter $(5 \mathrm{~cm}$ classes), height (nearest $1.5 \mathrm{~m}$ ), mortality, crown damage, degree of lean, and its potential to function as a seed tree. In addition, regeneration viability was measured in a 4 milacre $\left(16.2 \mathrm{~m}^{2}\right)$ subplot within each larger plot. Regeneration was tallied by species group as either seedling if less than $2.5 \mathrm{~cm}$, or sapling if $2.5-12.4 \mathrm{~cm}$ at ground level.

For each watershed, average number of trees per hectare (no./ha) and basal area $\left(\mathrm{m}^{2} \mathrm{ha}^{-1}\right)$ were calculated by species group, and by mortality. Species groups were pine (Pinus sp. primarily Pinus taeda), oaks (Quercus sp. primarily $Q$. falcate, Q.nigra, Q.laurifolia, and Q. phellos), blackgum (Nyssa sylvatica), sweetgum (Liquidambar styraciflua) and other hardwoods. Standardized $t$ tests were performed to determine significant differences in tree counts on WS77 and WS80, both before and after hurricane Hugo. Every tree that was tallied was assumed to have been alive prior to the hurricane. The average number of seedlings and saplings (per hectare basis) for each species group were calculated similar to the tree data. However, in the regeneration tallies, red maple (Acer rubra) was tallied separately and blackgum included with other hardwoods. Standardized $t$ tests were applied to each species group to test differences between WS77 and WS80 for average number of seedlings and average number of saplings in each species group.

\subsection{Evaluation of tree inventory data using aerial imagery}

Since the inventory of WS77 (in 1991) was only conducted after salvage logging operations in late 1989, we were concerned that trees removed during salvage operations were not included in the 1991 inventory. An aerial photo appraisal was therefore conducted to estimate the possible error in tree inventory totals as a result of not accounting for the salvaged trees. A series of georeferenced aerial photos of WS77 and WS80 taken in the winter of 1983, were compared to data from the 1991 tree inventory. Plot outlines were projected onto the 1983 photos and the number of pine and hardwood trees was accounted for in each plot by visual inspection. These counts were then compared to the number of trees recorded on the plot in the 1991 inventory. 


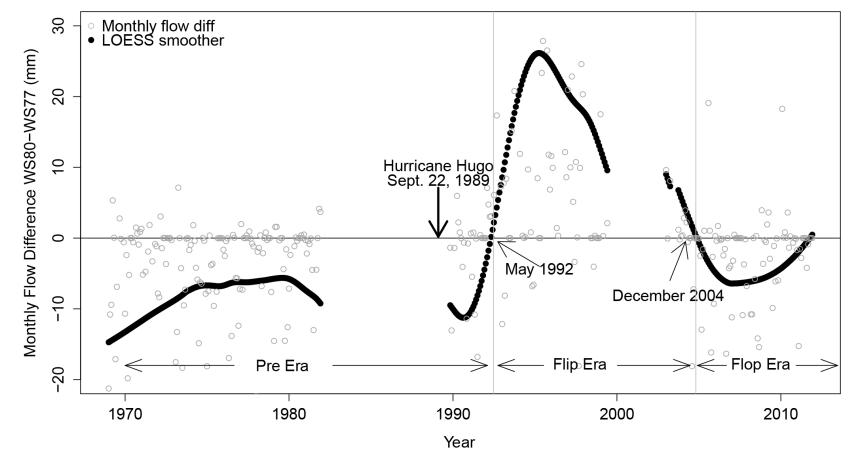

Fig. 3. A LOESS smoothing function (filled circles) was used to discern trends in monthly flow differences (open circles) between watershed 77 and watershed 80 . Hurricane Hugo struck the study watersheds in September 1989. The LOESS smoothing function crosses the $x$ axis at two points that mark the transition points between three eras: pre, flip and flop. Flow data were not recorded in the periods 1982-1989 and 1999-2002 due to discontinuation of streamflow monitoring for those periods. Points on the zerodifference line represent no-flow conditions in both watersheds, typically in late summer.

\section{Results}

\subsection{Determining the timing of change in hydrologic character}

A LOESS smoothing function with bandwidth of 0.31 (116.3 months) based on minimizing the AIC statistic for monthly flow difference data was used. The LOESS function clearly illustrated the reversal in relative streamflow magnitude between the two watersheds (Fig. 3). The smoothing function crosses the $x$ axis at two instances in time: May 1992 and December 2004. These two times demarcate the period when WS80 appeared to produce more flow than WS77 this time span is however very dependent on the bandwidth parameter. However, the MOSUM test detected changes in streamflow timing in the two watersheds by examining structural changes in the relationship in monthly runoff values between watersheds. The results of the MOSUM test for the two watersheds indicate three dates when significant structural changes occurred in the linear relationship of average monthly flows between WS77 and WS80 (Fig. 4a). The analyses were carried out on monthly data spanning the period 1969-2011 with several periods of missing data. Since MOSUM implementation with the "strucchange" package ignores missing data, the time axis have been rescaled based on the number of available data and exclude missing data. The break dates (and corresponding $95 \%$ confidence interval) are March 1993 (February 1993-April 1993), March 1994 (December 1993-April 1994), and April 2004 (November 2003August 2004). The first two break dates are only a year apart and therefore may be considered the same break period if a $99 \%$ confidence interval is considered.

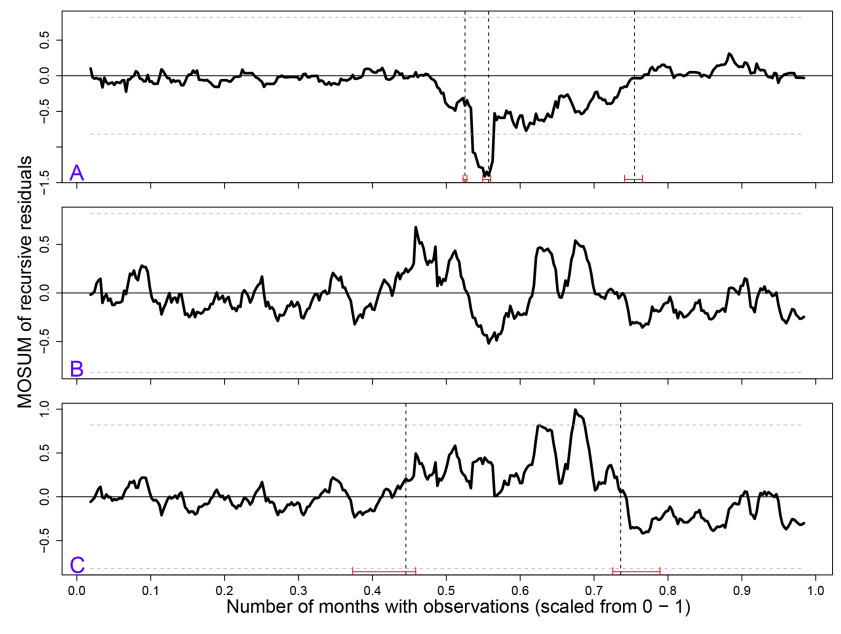

Fig. 4. Plots of MOSUM for the linear relationship (A) between watersheds, (B) between monthly flow and monthly rainfall in WS77, and $(\mathbf{C})$ between monthly flow and monthly rainfall in WS80. A shift of the MOSUM outside the $95 \%$ confidence intervals (horizontal dashed grey lines) indicates a structural break in the linear relationship. The vertical dotted lines in (A) and $(\mathbf{C})$ are estimated breakpoints (break dates). The corresponding red horizontal lines that cross each break date are the respective $95 \%$ confidence intervals for each break date. Because the analysis is on moving sums, the location where the MOSUM crosses the $95 \%$ confidence boundary is not always the location of the breakpoints. Also, when the MOSUM returns within the $95 \%$ confidence boundary, it does not mean the relationship has regained structural stability. There are three break dates in (A) corresponding to March 1993, March 1994, and April 2004. The first break date in (C) corresponds to June 1990 while the second break date corresponds to April 2003.

Results of the MOSUM test on the individual watersheds reveal no significant structural change in the monthly rainfall-runoff relationship on WS77 because the moving sums of recursive residuals do not cross the $95 \%$ confidence interval (Fig. 4b). However, a significant change in the rainfall-runoff relationship is detected for WS80 (Fig. 4c). The structural shifts on WS80 were predicted to have occurred in June of 1990 with a $95 \%$ confidence interval of occurrence between August 1980 and February 1991. The large confidence interval is due to the missing data. The second break date is April 2003 (95\% confidence interval: June 1999-May 2005).

The difference in the two major break dates for WS77 and WS80 derived from a MOSUM analysis of the linear relationship of flows between watersheds, and MOSUM analyses of watershed-specific rainfall-runoff relationships is attributed to differences in the strength of the respective relationships (adjusted $R^{2}$ of 0.8 for flows between watersheds, compared to $R^{2}$ of 0.4 for the two rainfall-runoff relationships). For example, the rainfall data used in this analysis was measured at the SEF headquarters, $2.9 \mathrm{~km}$ from WS80 and $3.9 \mathrm{~km}$ from WS77, and may not fully represent a rainfall 
incident on WS77 and WS80. While the results reported here are based on the use of a moving window size of 12 months, use of a window size of 6 months and 24 months only altered the reported break dates by one to three months respectively.

To summarize, the change dates for the onset of the flip era ranged from June 1990 (MOSUM: rainfall-runoff relationships for each watershed) to March 1993 (MOSUM: runoff relationships between watersheds). The return to normal conditions, or the onset of the flop era ranged from April 2003 (MOSUM: monthly runoff relationships between watersheds) to December 2004 (LOESS). For the sake of further analyses and to ease the process of estimating annual rainfall and runoff yields, the nearest January to range midpoints were chosen - the flip era was considered to have started in January 1992 and the flop era to have started in January 2004.

\subsection{Quantifying rainfall and streamflow changes in WS77 and WS80}

Concurrent rainfall data from the two watersheds comprised a temporally limited data set representing only 2 years in the pre era, 4 years of the flip era, and 8 years of the flop era. An analysis of concurrent rainfall data using three-way between groups ANOVA showed there was no significant three-way interaction among the three factors: watershed, month-ofyear, and era. The only interaction term that had a significant effect on monthly rainfall totals was between month-of-year and era $(F(22,308)=2.45, p<0.001)$. Of the three main effects tested, month-of-year had the most significant effect on monthly rainfall totals $(\mathrm{F}(11,308)=9.74, p<0.001)$; era was also significant but to a lesser degree $(\mathrm{F}(2,308)=4.61$, $p=0.01$ ). However, since the pre era was represented by only 2 years of concurrent rainfall data, ANOVA results using era as a factor should be interpreted with caution. Of primary importance however is that the main effect of watershed was not significant $(F(1,308)=0.15, p=0.70)$, as this suggests that monthly rainfall totals were not significantly different between the two watersheds. Monthly rainfall totals grouped by era for the periods of concurrently available rainfall data are illustrated in Fig. 5. Given the similarity of rainfall across the two watersheds, we believe that relative changes in streamflow are a good indicator of relative changes in evapotranspiration dynamics between the two watersheds.

During the years corresponding to watershed calibration (1969-1976), average monthly runoff from WS77 exceeded WS 80 by $9.1 \pm 1.8 \mathrm{~mm} \mathrm{month}^{-1}$. During the treatment years (1977-1981), mean monthly flows in WS77 exceeded WS80 by $6.1 \pm 1.7 \mathrm{~mm} \mathrm{month}^{-1}$ (Fig. 6). However, no significant difference in streamflow between the watersheds after partial prescribed burning was reported by Richter et al. (1983a). For the period immediately following Hugo in 1989 to the end of 1991 marking the end of the pre era, flows in both watersheds increased by about $28 \%$ compared to the calibration period (1969-1976) (Table 1 and analysis of

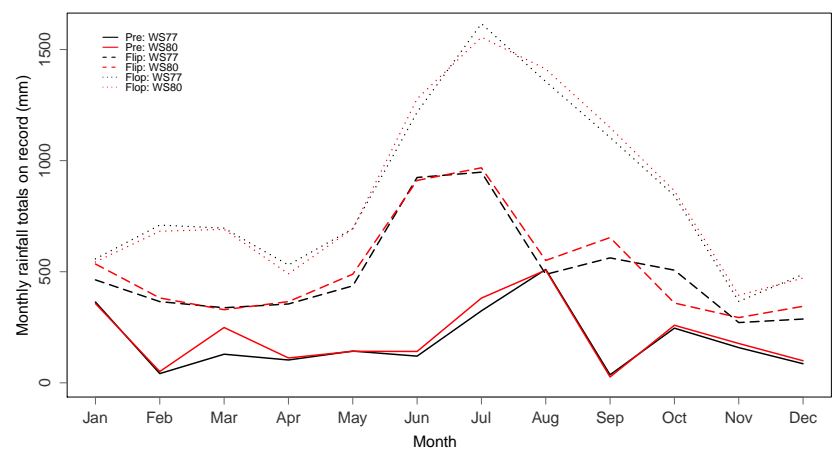

Fig. 5. Monthly rainfall totals in the two study watersheds grouped by the three eras; pre: 1969-1991, flip: 1992-2003, flop: 20042011. These data represent only concurrently measured rainfall in WS77 and WS80. Concurrently measured rainfall data in the two watersheds were available during the periods 1990-1997, 20012008, and 2010-2011.

WS80 by Wilson et al. (2006)). The relative difference in monthly mean flows suggests that WS77 was still exhibiting higher monthly streamflow $\left(11.5 \pm 4.4 \mathrm{~mm} \mathrm{month}^{-1}\right)$. During the flip era (from 1992 to the end of 2003) however, mean monthly flows in WS80 exceeded WS77 by $17.1 \pm$ $3.4 \mathrm{~mm} \mathrm{month}^{-1}$. Also during the flip era, mean monthly flows in WS77 were similar to the calibration period, while mean monthly flows in WS80 during the flip era were $111.4 \%$ more than the calibration period. After 2004, WS77 reverted to producing over $3.9 \mathrm{~mm} \mathrm{month}^{-1}$ more streamflow than WS80, and streamflow from both watersheds comprised the smallest proportion of rainfall compared to previous eras (Table 1).

\subsection{Forest response to Hurricane Hugo}

\subsubsection{Comparing tree inventory data with aerial image interpretation (nonsalvage plots)}

Counts of pine tree on 57 nonsalvage plots by aerial photo interpretation correlated well with tree inventory data from those plots $(R=0.70, p<0.01, N=57)$. The differences in mean count were not significant, with trees counted by aerial photography (6.74 trees per plot) fewer in number than those counted by tree inventory (7.60 trees per plot). Comparison of hardwood tree counts between tree inventory data and aerial photo interpretation revealed a lower but still significant correlation $(R=0.33, p=0.03)$. A nonsignificant difference of $1.51(\alpha=0.05)$ more hardwood trees per plot was seen in the tree inventory data when compared to aerial photography interpretation. Overall, there was a nonsignificant difference of 1.88 more trees per nonsalvaged plot based on using the two methods, with tree inventory data yielding a slightly higher tree count than by aerial photo interpretation. 
Table 1. Mean monthly flows, change in flows, and rainfall by era for WS77 and WS80. Percent change in flow by era were calculated with respect to flow during the calibration period (pre era: 1969-1976).

\begin{tabular}{|c|c|c|c|c|c|c|c|}
\hline \multirow[b]{2}{*}{ Era } & \multirow[b]{2}{*}{ Years } & \multicolumn{2}{|c|}{ WS77 } & \multicolumn{2}{|c|}{ WS80 } & \multirow[b]{2}{*}{$\begin{array}{l}\text { Avg. mo. flow } \\
\text { diff. }(\mathrm{mm}) \pm \mathrm{SE}\end{array}$} & \multirow[b]{2}{*}{$\begin{array}{l}\text { Avg. mo. rainfall } \\
(\mathrm{mm}) \pm \mathrm{SE}\end{array}$} \\
\hline & & $\begin{array}{l}\text { Avg. mo. flow } \\
(\mathrm{mm}) \pm \mathrm{SE}\end{array}$ & $\begin{array}{l}\text { Change } \\
\%\end{array}$ & $\begin{array}{l}\text { Avg. mo. flow } \\
(\mathrm{mm}) \pm \mathrm{SE}\end{array}$ & $\begin{array}{l}\text { Change } \\
\%\end{array}$ & & \\
\hline \multirow[t]{3}{*}{ Pre } & 1969-1976 & $31.7 \pm 4.5$ & & $22.6 \pm 3.1$ & & $-9.1 \pm 1.8$ & $117.1 \pm 7.7$ \\
\hline & 1977-1981 & $24.6 \pm 5.5$ & -22.6 & $18.5 \pm 4.4$ & -18.1 & $-6.1 \pm 1.7$ & $111.2 \pm 10.1$ \\
\hline & 1989-1991 & $40.6 \pm 12.9$ & +28.0 & $29.1 \pm 8.7$ & +28.7 & $-11.5 \pm 4.4$ & $87.6 \pm 16.0$ \\
\hline Flip & $1992-2003$ & $30.6 \pm 4.1$ & -3.5 & $47.7 \pm 5.2$ & +111.4 & $17.1 \pm 3.4$ & $104.5 \pm 8.9$ \\
\hline Flop & 2004-2011 & $19.4 \pm 3.2$ & -38.9 & $15.5 \pm 2.8$ & -31.4 & $-3.9 \pm 1.1$ & $108.5 \pm 7.2$ \\
\hline
\end{tabular}

\subsubsection{Estimating missing trees in WS77 due to salvage (salvage plots)}

Sixty-two of the plots on WS77 measured in 1991 had evidence of salvage logging, noted in the plot summaries. Counts of pine trees by aerial photography on 62 salvaged plots and by tree inventory showed significant but low correlation $(R=0.34, p<0.01, N=62)$. Similarly, counts of hardwood trees in salvaged plots counted by aerial photo interpretation and by tree inventory were also significant but low $(R=0.33, p<0.01, N=62)$. The comparison of inventory data to aerial photo interpretation in salvaged plots showed a significantly greater number of pine trees $(2.32$ more trees per plot, $p<0.01)$ and hardwood trees $(0.86$ more trees per plot) in counts made by aerial photography. Overall, there were a significantly greater number of trees $(3.18$ more trees per plot, $p<0.01)$ that were counted through aerial photo interpretation than by tree inventory, indicating that salvage removed 3.18 pines and 0.86 hardwoods per plot prior to the 1991 inventory. On extrapolation of these plot data to the entire watershed, the data suggest that 28.9 pine and 11.0 hardwood trees per hectare were salvaged in WS77 after Hugo. The average diameter (dbh) of the largest dead trees on each salvaged plot was $43.2 \mathrm{~cm}$. Assuming that salvaged trees were at least as large as the remaining dead trees, the data suggest that $4.3 \mathrm{~m}^{2} \mathrm{ha}^{-1}$ of pine and $1.5 \mathrm{~m}^{2} \mathrm{ha}^{-1}$ of hardwood basal area were removed from WS77 during the salvage operations. All subsequent presentation of tree density and basal area data include salvage count estimates based upon aerial photo interpretation.

\subsubsection{Analysis of plot inventory data}

Prior to Hugo, our data indicate that WS80 (186.8 trees ha $\left.{ }^{-1}\right)$ had significantly fewer trees per unit area of watershed compared to WS77 (263.4 trees ha $\left.{ }^{-1}\right)$. In terms of basal area however, tree density in WS80 $\left(16.3 \mathrm{~m}^{2} \mathrm{ha}^{-1}\right)$ was comparable to WS77 $\left(18.3 \mathrm{~m}^{2} \mathrm{ha}^{-1}\right.$ ) (Table 2). In addition, $45 \%$ of all trees in WS80 were pine accounting for $65 \%$ of basal area in that watershed. In WS77, pre-Hugo estimates sug-

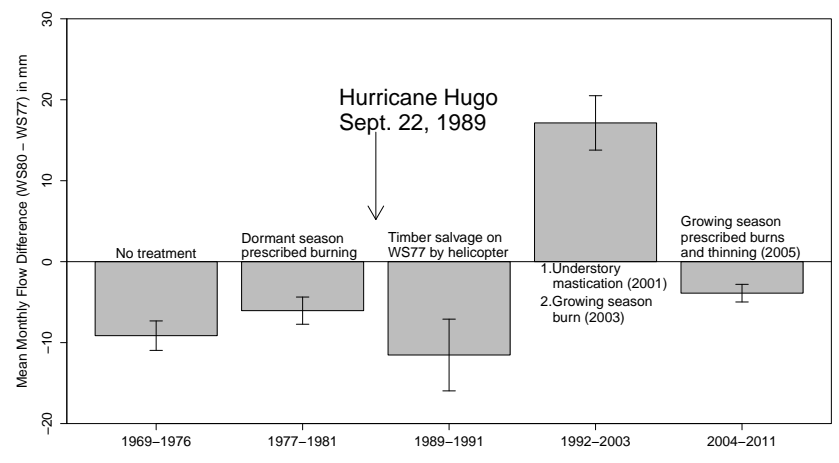

Fig. 6. Mean monthly flow differences between WS77 and WS80 from 1969 to 2011 . No records were collected from 1982 to September 1989. Listed treatments were applied only in WS77.

gest that $79 \%$ of all trees counted were pine that accounted for $81 \%$ of basal area. The average basal area of a pine was 0.13 and $0.07 \mathrm{~m}^{2}$ tree ${ }^{-1}$ in WS80 and WS77, respectively. After the passage of Hurricane Hugo, $35.7 \%$ of the trees in WS80 experienced mortality accounting for $55.4 \%$ of basal area. In WS77, $38.5 \%$ of the trees lost to the storm accounted for $54.5 \%$ of basal area. It appears that mortality rates were similar in both watersheds. After Hugo, the pine trees that withstood Hugo had average basal areas of $0.10 \mathrm{~m}^{2}$ tree $^{-1}$ and $0.05 \mathrm{~m}^{2}$ tree $^{-1}$ in WS80 and WS77, respectively (Fig. 7). Overall, the average basal area per tree decreased by $30.7 \%$ in WS80 and $26.0 \%$ in WS77. In addition to greater basal area of trees, WS77 also had significantly $(\alpha=0.05)$ more seedling regeneration than WS80 (Table 3). WS80 showed an advantage in terms of regeneration only for oak saplings. Although the distribution of pine saplings was quite variable, WS77 averaged more than three times the number of pine saplings than WS80. 
Table 2. Results from tree inventory data from 1991 that recorded mortality and living trees. Trees alive pre-Hugo were estimated by summing the following: alive post-Hugo + recorded mortality + salvage. Counts of trees salvaged from WS77 post-Hugo were inferred by aerial photo interpretation. Significance of $t$ tests of differences in mean number of trees and mean basal area between WS77 and WS80 are shown. Standardized $t$ test: mean WS80 $\neq$ WS 77; ${ }^{* *}$ significant at $\alpha=0.01{ }^{*}$ significant at $\alpha=0.05$; NS not significant $\alpha=0.05$; HWD hardwood species.

\begin{tabular}{|c|c|c|c|c|c|c|c|c|}
\hline & \multicolumn{3}{|c|}{ Alive pre-Hugo } & \multicolumn{3}{|c|}{ Alive post-Hugo } & \multicolumn{2}{|c|}{ Percentage loss } \\
\hline & WS80 & WS77 & Sig. & WS80 & WS77 & Sig. & WS80 & WS77 \\
\hline \multicolumn{9}{|c|}{ Number of trees per hectare } \\
\hline Pine & 83.5 & 208.8 & $* *$ & 28.7 & 119.8 & $* *$ & 65.7 & 42.6 \\
\hline Oaks & 35.3 & 19.6 & NS & 32.1 & 8.2 & NS & 9.1 & 58.5 \\
\hline Blackgum & 27.4 & 20.0 & NS & 26.9 & 19.5 & NS & 1.8 & 2.5 \\
\hline Sweetgum & 19.3 & 10.6 & NS & 17.5 & 10.4 & NS & 9.0 & 2.3 \\
\hline Other HWD & 21.3 & 4.2 & NS & 14.8 & 4.0 & NS & 30.2 & 5.9 \\
\hline Total & 186.8 & 263.3 & ** & 120.1 & 161.9 & $* *$ & 35.7 & 38.5 \\
\hline \multicolumn{9}{|c|}{ Basal Area $\left(\mathrm{m}^{2} \mathrm{ha}^{-1}\right)$} \\
\hline Pine & 10.6 & 14.9 & $* *$ & 2.8 & 6.5 & $* *$ & 73.2 & 56.5 \\
\hline Oaks & 8.9 & 3.5 & $* *$ & 1.5 & 0.4 & $*$ & 24.7 & 77.7 \\
\hline Blackgum & 1.2 & 0.7 & NS & 1.2 & 0.7 & NS & 1.9 & 3.2 \\
\hline Sweetgum & 1.2 & 0.3 & $* *$ & 1.1 & 0.3 & $* *$ & 13.0 & 0.0 \\
\hline Other HWD & 1.2 & 0.4 & NS & 0.6 & 0.4 & NS & 48.1 & 5.6 \\
\hline Total & 16.3 & 18.3 & NS & 7.3 & 8.3 & $*$ & 55.4 & 54.5 \\
\hline
\end{tabular}

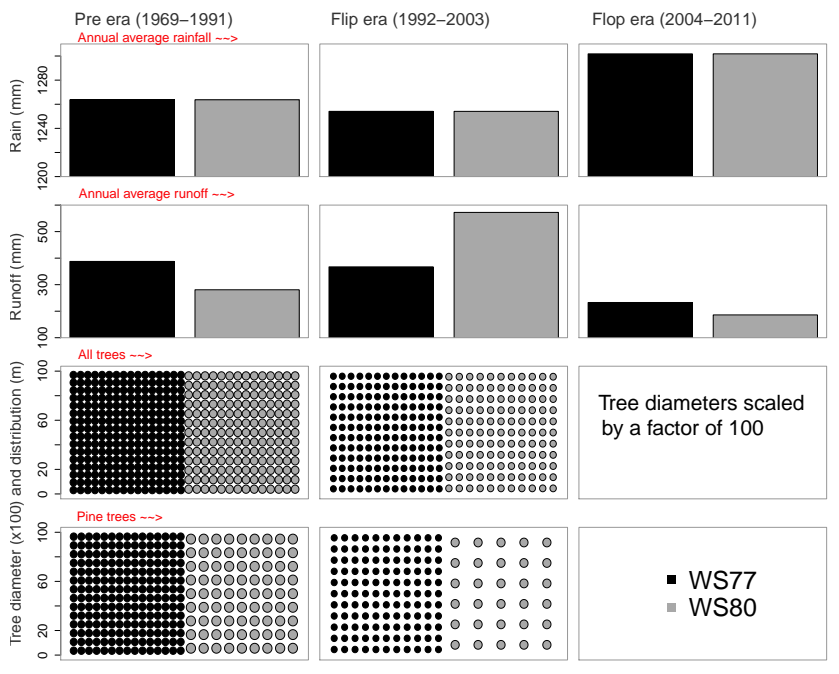

Fig. 7. Changes in rainfall, runoff and forest structure in WS77 and WS80 before (pre era) and after Hugo (flip and flop eras). Lower four panels show the number of all trees or only pine trees (lowest row) within a 1 ha plot. Tree diameters are scaled by a factor of 100 . The sum of shaded areas in each watershed represents a consistently scaled approximation of basal area per hectare before (pre era) and after (flip era) Hugo. Refer to Table 2 for more details.
Table 3. Results of regeneration counts made during inventories of WS77 and WS80 in 1991. All values represent the number of trees per hectare. Statistical significance as denoted in Table 2 .

\begin{tabular}{lrrrrrrrr}
\hline & \multicolumn{3}{c}{ Seedlings } & & \multicolumn{3}{c}{ Saplings } \\
\cline { 2 - 3 } \cline { 7 - 9 } & WS80 & WS77 & Sig. & & WS80 & WS77 & Sig. \\
\hline Pine & 329 & 792 & $* *$ & & 34 & 117 & NS \\
Oaks & 132 & 229 & $*$ & & 35 & 13 & $* *$ \\
Sweetgum & 250 & 544 & $*$ & & 48 & 38 & NS \\
Red maple & 48 & 56 & NS & & 28 & 26 & NS \\
Other HWD & 76 & 53 & NS & & 67 & 14 & NS \\
\hline Total & 749 & 1466 & $*$ & & 199 & 163 & NS \\
\hline
\end{tabular}

\section{Discussion}

Flow from the paired watershed experiment showed a stable difference in flow generation from 1969 through 1992 even after an extreme event like Hurricane Hugo in 1989. Throughout that period, flow from WS77 was consistently higher than WS80. From 1993 until 2003, flow from WS80 consistently exceeded flow from WS77. The flip in relationship represented a relative increase of flow in WS80 of $28 \mathrm{~mm} \mathrm{month}^{-1}$. This change was confirmed by three analyses of monthly flow data (1 - MOSUM: rainfall-runoff relationships for each watershed; 2 - MOSUM: runoff relationships between watersheds, and 3 - LOESS), all of which found significant change centered around 1992. 
The analysis of monthly flow data by LOESS showed a definitive alteration in relative monthly flows several years after the impact of Hurricane Hugo. An analysis of structural change in the flow relationships between watersheds showed that the timing of this reversal in relative streamflow magnitude occurred sometime between June 1990 and March 1993. The timing of the return to pre-calibration conditions occurred between April 2003 and December 2004. A structural analysis of rainfall-runoff relationships for each watershed by MOSUM revealed that significant changes were detected in WS80 but not in WS77, with a change in the direction of greater runoff production in WS80.

The analysis of vegetation data post-hurricane in WS77 showed a greater abundance of pine seedlings and therefore a greater regenerative potential, leading to greater transpirative losses as the pines matured in the years following Hugo. In WS80, vegetation analyses showed that the removal of tall/older trees was the primary impact of the hurricane. The loss of larger trees in WS80 combined with the paucity of seedlings for regeneration likely lowered transpirative losses in the years after the hurricane. Both the runoff data in Table 1 and the MOSUM analysis suggest the main cause of the flip was due to increased flow in WS80 over the period 19902003. Increased flow in WS77 occurred only until 1993 and the rainfall-runoff relation did not exceed the bounds of expected variability. Vegetation analysis suggests that rapid growth of seedlings and young pine in WS77 led to higher evapotranspiration losses and therefore lower runoff. These results are consistent with Kuczera (1987), who also showed that after an artificial disturbance, forest age and composition were responsible for short-term changes in streamflow and long-term recovery to predisturbance conditions.

The impact of Hugo on the vegetation of WS77 and WS80 is consistent with our knowledge of hurricane impact on southern forests. The inventory of WS 80 showed that mortality was greatest among large diameter pines, which were primarily loblolly pine. While pine was the predominant species in both watersheds, WS80 had fewer pine trees than WS77; however, each tree in WS80 was on average twice the size of a pine tree (in terms of basal area per tree) in WS77. Since the number of dead trees comprised about one-third of all trees counted across both watersheds, but account for over half of the basal area lost in the hurricane, the data clearly show that hurricane winds affected larger trees in both watersheds (refer to Fig. 7).

Large diameter loblolly pines (Pinus taeda) were also found highly susceptible to breakage according to Gresham et al. (1991) as well as by Putz and Sharitz (1991) in their study of Hurricane Hugo's damage. Gresham et al. (1991) also found that water oak (Quercus laurifolia), and laurel oak (Quercus hemisphaerica) were susceptible to wind breakage as was the case for oaks on WS80. In WS80, sweetgum (Liquidambar styraciflua) and blackgum (Nyssa sylvatica) received much less damage than pines or oaks, consistent with several other studies (Putz and Sharitz, 1991; Duever and
McCollom, 1992; Stanturf et al., 2007). The tree inventory data from WS77 showed similar survival of smaller pines, sweetgum, and blackgum. If the estimated $4.3 \mathrm{~m}^{2} \mathrm{ha}^{-1}$ of salvaged pine (most likely to be large pines) is added to the $4.1 \mathrm{~m}^{2} \mathrm{ha}^{-1}$ of pine loss from the inventory data, pine tree mortality due to Hugo on WS77 $\left(8.4 \mathrm{~m}^{2} \mathrm{ha}^{-1}\right)$ and WS80 $\left(7.8 \mathrm{~m}^{2} \mathrm{ha}^{-1}\right)$ become comparable. This result agrees with work done by Hook et al. (1991) in the Francis Marion National Forest that shows uniform destruction of large pines located in proximity to the path of the hurricane center.

Preexisting variation in forest structure was shown by Foster (1988) to be a strong predictor of hurricane damage. Although large trees were destroyed by the hurricane on both watersheds, young pines planted on WS77 from 1982 to 1989 had survived and represented $6.3 \mathrm{~m}^{2} \mathrm{ha}^{-1}$ of basal area by 1991. In addition, WS77 had twice as many pine seedlings and more pine saplings per hectare than WS80. Young pines have much higher water use rates than mature pines (Irvine et al., 2004) due to both leaf area and high transpiration per unit leaf area (Delzon and Loustau, 2005). Song et al. (2012) analyzed the recovery of South Carolina forests after Hugo four of their 1 ha plots are located in WS80 and were measured from 1994 through 2012. Their data from WS80 show that pine tree basal area increased from $6 \mathrm{~m}^{2} \mathrm{ha}^{-1}$ in 1994 to $9 \mathrm{~m}^{2} \mathrm{ha}^{-1}$ by 2003 . Water oak, the other species to show notable growth, grew from $1.4 \mathrm{~m}^{2} \mathrm{ha}^{-1}$ in 1994 to $1.7 \mathrm{~m}^{2} \mathrm{ha}^{-1}$ by 2003 . Cosentino (2013) found that spectral reflectance (normalized difference vegetation index) on the entire SEF had recovered to pre hurricane levels by 1999 . These data suggest that the regeneration on WS77 allowed that watershed to resume normal evapotranspiration by 1993 but that regeneration on WS80 did not reach that level until 2003.

Vegetation inventory and regeneration counts suggest the strong influence of evapotranspiration on hydrologic processes in the two watersheds. Throughout the calibration and early prescribed burning experiments, WS77 consistently produced more runoff than WS80. The inventory suggests WS77 had an abundance of smaller pine, more pine seedlings and more pine saplings in comparison to WS80 at the time of inventory. Many of these small pines were the result of regeneration experiments conducted on WS77 during the 1982-1989 period when no hydrological measurements were undertaken. Hurricane Hugo struck these watersheds in September of 1989 and destroyed the larger pines and hardwoods (predominantly oaks) present on both watersheds. Following the hurricane, WS77 had double the pine tree basal area, twice as many pine seedlings and three times more pine saplings than WS80. The rapid regrowth of pines on WS77 appears to be responsible for near-normal evapotranspiration from 1993 to 2003, while delayed regrowth on WS80 limited evapotranspiration losses that manifested as increased runoff at its watershed outlet.

The return to historical conditions (onset of flop era) corresponded to 2 years that were marked by high rainfall (2003: $300 \mathrm{~mm}$ above annual average) followed by very dry 
conditions (2004: $400 \mathrm{~mm}$ below the annual average). Differences in water table position has been shown to be a primary cause for variability in the relationship between rainfall and runoff (Epps et al., 2013; La Torre Torres et al., 2011; Harder et al., 2007; Young and Klawitter, 1968). This high variability is probably responsible for the low $\mathrm{R}^{2}$ values found by MOSUM analysis, although using rainfall measurements from the relatively distal Santee headquarters rain gauge (refer Fig. 1) may also be partly to blame. In any case, the inability of the MOSUM analysis to detect significant changes in WS77 post-hurricane precludes a quantitative estimate of the timing of recovery on WS77. It seems likely that high rainfall in 2003 would have created saturated soils on both watersheds during that year, with substantial water table draw down during the following year's (2004) drought conditions. Whether this accelerated the return to historical conditions is an area for further study. Unfortunately there were also understory mechanical treatments conducted on WS77 in 2001 and growing season fire treatments (for more on fire treatments please refer to Richter et al. $(1982,1983)$ ) in 2003, which might also have decreased ET on WS77. The exact timing and mechanisms responsible for the onset of the flop period are therefore somewhat confounded, however, since around 2004 the watersheds have returned to a relative state similar to that of the pre era.

\section{Conclusions}

The functional relationship between vegetation and hydrologic processes in southeastern coastal forests presents a complex and understudied area for research. In this study, we demonstrated a gradual but definitive shift in the hydrologic character of a coastal watershed that was impacted by a hurricane. We linked the change in the rainfall-runoff relationship to a shift in forest vegetation due to selective hurricane damage. While both watersheds were located in the path of the hurricane, extant forest structure varied between the two watersheds as a function of experimental forest management techniques on the treatment watershed. We showed that the primary damage was to older pines, and to some extent larger hardwood trees. We believe that lowered vegetative water use impacted both watersheds with increased outflows on both watersheds due to loss of trees following hurricane impact. However, one watershed was able to recover to pre hurricane levels of canopy evapotranspiration at a quicker rate due to the greater abundance of pine seedlings and saplings in that watershed. With the return to a closed canopy forest structure, the subsequent growth and increased water use by trees in the impacted watershed, there appears to be a return to the original hydrologic state witnessed prior to the passage of the hurricane.

A careful study of hurricane impact can reveal information that is missed by broad-scale evaluations that are typically conducted immediately after a major hurricane. Those immediate studies have done well to improve our understanding of the overall impact of hurricanes to southeastern coastal forested watersheds - this study confirms those overall understandings. However, by applying those principles to varying initial stand conditions, one can expect a range of different impacts on the forest that can eventually lead to unexpected long-term impacts on ecosystem services. This work demonstrates the importance of long-term monitoring of paired watersheds and modern quantitative methods to examine subtle changes in ecological impacts of climatic events that can have important consequences for hydrologic processes. Without these data and analyses, the differences caused by slightly altered forest conditions prior to a hurricane would not have been expected to have such a large and delayed impact on streamflow.

For future work, there is a critical need for an explicit coupling of hydrologic and vegetative growth models using directly measured transpirative losses to simulate and validate the impacts of sudden and/or long-term perturbations to the eco-hydrologic characteristics of a coastal forested watershed.

Acknowledgements. The authors thank Andy Harrison for his significant contributions in assembling streamflow and rainfall data for watersheds 77 and 80. Dr. Jayakaran's contribution is based upon work supported by NIFA/USDA project number SC1700394, technical contribution number 6165 of the Clemson University Experiment Station.

Edited by: P. Passalacqua

\section{References}

Adamowski, J., Fung Chan, H., Prasher, S. O., Ozga-Zielinski, B., and Sliusarieva, A.: Comparison of multiple linear and nonlinear regression, autoregressive integrated moving average, artificial neural network, and wavelet artificial neural network methods for urban water demand forecasting in Montreal, Canada, Water Resour. Res., 48, W01528, doi:10.1029/2010WR009945, 2012.

Aikaike, H.: Information theory and an extension of the maximum likelihood principle, in: Proceedings of the Second International Symposium on Information Theory, edited by: Petrov, B. N. and Caski, F., 267-281, Budapest: Akademiai Kiado, 1973.

Amatya, D. M. and Radecki-Pawlik, A.: Flow dynamics of three forested watersheds in coastal South Carolina, USA, ACTA Scientarium Polonorum Formatio Circumiectus, 6, 3-17, 2007.

Amatya, D. M. and Skaggs, R. W.: Long-term hydrology and water quality of a drained pine plantation in North Carolina, Trans. ASABE, 54, 2087-2098, 2011.

Amatya, D. M. and Trettin, C. C.: Development of watershed hydrologic studies at Santee Experimental Forest, South Carolina, in: Proceedings of the Forest Service National Earth Sciences Conference, edited by: Furniss, M., C. Clifton, C., and Ronnenberg, K., PNW-GTR-689, 180-190, Portland, OR, 2007. 
Amatya, D. M., Trettin, C., Skaggs, R., and Gregory, J.: Effects of controlled drainage on the hydrology of drained pine plantations in the North Carolina coastal plain, J. Hydrol., 181, 211-232, 1996.

Amatya, D. M., Sun, G., Trettin, C. C., and Skaggs, R. W.: Longterm forest hydrologic monitoring in coastal Carolinas, in: First Interagency Conference on Research in the Watersheds, edited by: Renard, K. G., McElroy, S. A., Gburek, W. J., Canfield, H. E., and Scott, R. L., 279-285, US Department of Agriculture, Agricultural Research Service, 2003.

Amatya, D. M., Miwa, M., Harrison, C. A., Trettin, C. C., and Sun, G.: Hydrology and water quality of two first order watersheds in coastal South Carolina, in: Annual International Meeting, Paper no 062182 , p. 21, American Society of Agricultural Engineers, St. Joseph, 2006.

Andreassian, V.: Waters and forests: from historical controversy to scientific debate, J. Hydrol., 291, 1-27, 2004.

Bai, J.: Least squares estimation of a shift in linear processes, J. Time Ser. Anal., 15, 453-472, 1994.

Bai, J.: Estimating multiple breaks one at a time, Econom. Theory, 13, 315-352, 1997.

Bai, J. and Perron, P.: Estimating and testing linear models with multiple structural changes, Econometrica, 66, 47-78, 1998.

Balshi, M. S., Mcguire, A. D., Duffy, P., Flannigan, M., Walsh, J., and Melillo, J.: Assessing the response of area burned to changing climate in western boreal North America using a Multivariate Adaptive Regression Splines (MARS) approach, Global Change Biol., 15, 578-600, 2009.

Bauer, P. and Hackl, P.: The use of MOSUMS for quality control, Technometrics, 20, 431-436, 1978.

Binstock, D. A.: Effects of a prescribed winter burn on anion nutrient budgets in the Santee Experimental Forest ecosystem, Ph.d. dissertation, Duke University, Durham, NC, 1978.

Bokaw, N. V. L. and Walker, L. R.: Summary of the effects of Caribbean hurricanes on vegetation, Isotropic, 23, 442-447, 1991.

Brennen, J. W.: Meteorological summary of Hurricane Hugo, J. Coast. Res., 8, 13-24, 1991.

Brown, R. L., Durbin, J., and Evans, J. M.: Techniques for testing the constancy of regression relationships over time, J. Roy. Stat. Soc., 37, 149-192, 1975.

Bryant, M. L., Bhat, S., and Jacobs, J. M.: Measurements and modeling of throughfall variability for five forest communities in the southeastern US, J. Hydrol., 312, 95-108, 2005.

Callahan, T. J., Vulava, V. M., Passarello, M. C., and Garrett, C. G.: Estimating groundwater recharge in lowland watersheds, Hydrol. Process., 26, 2845-2855, 2012.

Caporale, G. M., Ciferri, D., and Girardi, A.: Fiscal shocks and real exchange rate dynamics: Some evidence for Latin America, J. Int. Money Finance, 30, 709-723, 2011.

Chu, C.-S. J., Hornik, K., and Kaun, C.-M.: MOSUM tests for parameter constancy, Biometrika, 82, 603-617, 1995.

Cleveland, W. and Grosse, E.: Computational methods for local regression, Stat. Comput., 1, 47-62, 1991.

Cosentino, G. R.: Comparing Vegetation Cover in the Santee Experimental Forest, South Carolina (USA), Before and After Hurricane Hugo: 1989-2011, Masters thesis, Georgia State University, available at: http://digitalarchive.gsu.edu/geosciences_theses/58, 2013.
Dai, Z., Amatya, D. M., Sun, G., Trettin, C. C., Li, C., and Li, H.: Climate Variability and Its Impact on Forest Hydrology on South Carolina Coastal Plain, USA, Atmosphere, 2, 330-357, 2011.

Dai, Z., Trettin, C. C., and Amatya, D. M.: Effects of climate variability on forest hydrology and carbon sequestration on the Santee Experimental Forest in coastal South Carolina, Gen. Tech. Rep. SRS-GTR-172, USDA-Forest Service, Southern Research Station, Asheville, NC, 2013.

de Jong, R., Verbesselt, J., Schaepman, M. E., and de Bruin, S.: Trend changes in global greening and browning: contribution of short-term trends to longer-term change, Global Change Biol., 18, 642-655, 2012.

de Jong, R., Verbesselt, J., Zeileis, A., and Schaepman, M. E.: Shifts in global vegetation activity trends, Remote Sens., 5, 1117-1133, 2013.

Delzon, S. and Loustau, D.: Age-related decline in stand water use: sap flow and transpiration in a pine forest chronosequence, Agr. Forest Meteorol., 129, 105-119, 2005.

Domec, J.-C., Sun, G., Noormets, A., Gavazzi, M. J., A.Treasure, E., Cohen, E., Swenson, J. J., McNulty, S. G., and King, J. S.: A comparison of three methods to estimate evapotranspiration in two contrasting loblolly pine plantations: age-related changes in water use and drought sensitivity of evapotranspiration components, Forest Sci., 58, 497-512, 2012.

Duever, M. and McCollom, J.: Hurricane Hugo effects on oldgrowth floodplain forest communities at Four Hole Swamp, South Carolina., in: Proceedings of the Seventh Biennial Southern Silvicultural Research Conference, edited by: Brissette, J. C., Gen. Tech. Rept. SO-93, 197-202, USDA Forest Service, Southern Forest Experiment Station, New Orleans, LA, 1992.

Epps, T. H., Hitchcock, D. R., Jayakaran, A. D., Loflin, D. R., Williams, T. M., and Amatya, D. M.: Characterization of Storm Flow Dynamics of Headwater Streams in the South Carolina Lower Coastal Plain1, JAWRA J. Am. Water Resour. Assoc., 49, 76-89, 2013.

Everham, E. and Brokaw, N.: Forest damage and recovery from catastrophic wind, The Botanical Rev., 62, 113-185, 1996.

Ford, C. R., Hubbard, R. M., Kloeppel, B. D., and Vose, J. M.: A comparison of sap flux-based evapotranspiration estimates with catchment-scale water balance, Agr. Forest Meteorol., 145, 176185, 2007.

Forkel, M., Carvalhais, N., Verbesselt, J., Mahecha, M. D., Neigh, C. S. R., and Reichstein, M.: Trend Change Detection in NDVI Time Series: Effects of Inter-Annual Variability and Methodology, Remote Sens., 5, 2113-2144, 2013.

Foster, D. R.: Species and Stand Response to Catastrophic Wind in Central New England, USA, J. Ecology, 76, 135-151, 1988.

Friedman, J. H.: Multivariate Adaptive Regression Splines, The Annals of Statistics, 19, 1-67, 1991.

Ghosh, S.: Import demand of crude oil and economic growth: Evidence from India, Energy Pol., 37, 699 -702, 2009.

Gillham, R.: The capillary fringe and its effect on water-table response, J. Hydrol., 67, 307-324, 1984.

Gresham, C. A., Williams, T. M., and Lipscomb, D. J.: Hurricane Hugo Wind Damage to Southeastern U.S. Coastal Forest Tree Species, Biotropica, 23, 420-426, 1991. 
Harder, S. V., Amatya, D. M., Callahan, T. J., Trettin, C. C., and Hakkila, J.: Hydrology and Water Budget for a Forested Atlantic Coastal Plain Watershed, South Carolina, JAWRA J. Am. Water Resour. Assoc., 43, 563-575, 2007.

Haymond, J. L. and Harms, W. R.: Hurricane Hugo: South Carolina forest land research and management related to the storm, General Technical Report SRS-005, US Department of Agriculture, Forest Service, Southern Research Station, Asheville, NC, 1996.

Hewlett, J. D.: Principles of forest hydrology, University of Georgia Press, Athens, GA, 1982.

Hewlett, J. D., Lull, H. W., and Reinhart, K. G.: In Defense of Experimental Watersheds, Water Resour. Res., 5, 306-316, 1969.

Hook, D. D., Buford, M. A., and Williams, T. M.: Impact of Hurricane Hugo on the South Carolina Coastal Plain Forest, J. Coastal Res., 81, 291-300, 1991.

Hurvich, C. M., Simonoff, J. S., and Tsai, C.-L.: Smoothing parameter selection in nonparametric regression using an improved Akaike information criterion, J. Roy. Stat. Soc. B (Statistical Methodology), 60, 271-293, 1998.

Ice, G. and Stednick, J.: A century of forest and wildland watershed lessons, Soc. Am. Foresters, 2004.

Irvine, J., Law, B. E., Kurpius, M. R., Anthoni, P. M., Moore, D., and Schwarz, P. A.: Age-related changes in ecosystem structure and function and effects on water and carbon exchange in ponderosa pine, Tree Physiol., 24, 753-763, 2004.

Jasechko, S., Sharp, Z. D., Gibson, J. J., Birks, S. J., Yi, Y., and Fawcett, P. J.: Terrestrial water fluxes dominated by transpiration, Nature, 496, 347-350, 2013.

Johnston, R. S.: Evapotranspiration from bare, herbaceous, and aspen plots: A check on a former study, Water Resour. Res., 6, 324-327, 1970.

Klock, G. O. and Helvey, J. D.: Debris flows following wildfire in north central Washington, in: Proceedings of the Third Federal Interagency Sedimentation Conference, US Subcommittee on Sedimentation, Denver, CO, 1976.

Kuczera, G.: Prediction of water yield reductions following a bushfire in ash-mixed species eucalypt forest, J. Hydrol., 94, 215-236, 1987.

Kupfer, J., Myers, A., McLane, S., and Melton, G.: Patterns of Forest Damage in a Southern Mississippi Landscape Caused by Hurricane Katrina, Ecosystems, 11, 45-60, 2008.

La Torre Torres, I. B., Amatya, D. M., Sun, G., and Callahan, T. J.: Seasonal rainfall-runoff relationships in a lowland forested watershed in the southeastern USA, Hydrol. Process., 25, 20322045, 2011.

Lugo, A. E.: Visible and invisible effects of hurricanes on forest ecosystems: an international review, Austral Ecol., 33, 368-398, 2008.

Megahan, W. F.: Hydrologic effects of clearcutting and wildfire on steep granitic slopes in Idaho, Water Resour. Res., 19, 811-819, 1983.

Miwa, M., Gartner, D. L., Bunton, C. S., Humphreys, R., and Trettin, C. C.: Characterization of headwater stream hydrology in the southeastern Lower Coastal Plain, Final report to us epa. charleston, sc, USDA Forest Service, 2003.

Olmo, J., Pilbeam, K., and Pouliot, W.: Detecting the presence of insider trading via structural break tests, J. Banking Finance, 35, 2820-2828, 2011.
Peel, M. C.: Hydrology: catchment vegetation and runoff, Progr. Phys. Geogr., 33, 837-844, 2009.

Putz, F. E. and Sharitz, R. R.: Hurricane damage to old-growth forest in Congaree Swamp National Monument, South Carolina, U.S.A., Can. J. Forest Res., 21, 1765-1770, 1991.

RCoreTeam: R statistical software [version 2.15.2], 2012.

Richter, D. D., Ralston, C. W., and Harms, W. R.: Prescribed Fire: Effects on Water Quality and Forest Nutrient Cycling, Science, 215, 661-663, 1982.

Richter, D. D., Ralston, C. W., and Harms, W. R.: Chemical composition and spatial variation of bulk precipitation at a coastal plain watershed in South Carolina, Water Resour. Res., 19, 134-140, 1983.

Saghaei, A., Mehrjoo, M., and Amiri, A.: A CUSUM-based method for monitoring simple linear profiles, The Int. J. Adv. Manufact. Technol., 45, 1252-1260, 2009.

SCS: Soil survey of Berkeley County, South Carolina, Tech. rep., USDA Soil Conservation Service, Washington, D.C, 1980.

Skaggs, R. W., Chescheir, G. M., Fernandez, G. P., Amatya, D. M., and Diggs, J.: Effects of land use on the hydrology of drained coastal plain watersheds, Trans. ASABE, 54, 1357-1365, 2011.

Slattery, M. C., Gares, P. A., and Phillips, J. D.: Multiple modes of storm runoff generation in a North Carolina coastal plain watershed, Hydrol. Process., 20, 2953-2969, 2006.

Song, B., Gresham, C. A., Trettin, C. C., and Williams, T. M.: Monitoring the Recovery of Coastal Plain Forests from Hurricane Hugo, Tree Forest. Sci. Biotechnol., 6, 60-68, 2012.

Sparks, P. R.: Wind Conditions in Hurricane Hugo and their Effect on Buildings in Coastal South Carolina, Journal of Coastal Research, SPECIAL ISSUE NO. 8. Impacts of Hurricane Hugo, 13-24, 1991.

Ssegane, H., Amatya, D. M., Chescheir, G. M., Skaggs, W. R., Tollner, E. W., and Nettles, J. E.: Consistency of Hydrologic Relationships of a Paired Watershed Approach Before and After the Reversal of Control and Treatment Watersheds, Am. J. Climate Change, 2, 147-164, 2013

Stanturf, J. A., Goodrick, S. L., and Outcalt, K. W.: Disturbance and coastal forests: A strategic approach to forest management in hurricane impact zones, Forest Ecol. Manage., 250, 119-135, 2007.

Sun, G., Lu, J., Gartner, David L.and Miwa, M., and Trettin, C. C.: Water budgets of two forested watersheds in South Carolina, in: Spring Special Conference of the American Water Resources Association, 2000.

Sun, G., McNulty, S., Lu, J., Amatya, D., Liang, Y., and Kolka, R.: Regional annual water yield from forest lands and its response to potential deforestation across the southeastern United States, J. Hydrol., 308, 258-268, 2005.

Sun, G., Noormets, A., Gavazzi, M., McNulty, S., Chen, J., Domec, J.-C., King, J., Amatya, D., and Skaggs, R.: Energy and water balance of two contrasting loblolly pine plantations on the lower coastal plain of North Carolina, USA, Forest Ecology and Management, 259, 1299-1310, 2010.

Tian, S., Youssef, M. A., Skaggs, R. W., Amatya, D. M., and Chescheir, G. M.: DRAINMOD-FOREST: Integrated Modeling of Hydrology, Soil Carbon and Nitrogen Dynamics, and Plant Growth for Drained Forests, J. Environ. Qual., 41, 764-782, 2012. 
Tiwari, A. K., Shahbaz, M., and Islam, F.: Does financial development increase rural-urban income inequality?: Cointegration analysis in the case of Indian economy, Int. J. Soc. Econom., 40, 151-168, 2012.

Troendle, C. A. and King, R. M.: The Effect of Timber Harvest on the Fool Creek Watershed, 30 Years Later, Water Resour. Res., 21, 1915-1922, 1985.

Tsutsumida, N., Saizen, I., Matsuoka, M., and Ishii, R.: Land Cover Change Detection in Ulaanbaatar Using the Breaks for Additive Seasonal and Trend Method, Land, 2, 534-549, 2013.

USDAFS: The Wetlands - watershed managements new frontier, Tech. rep., USDA Forest Service, Southern Forest Experiment Station, Asheville, NC, 1963.

Verbesselt, J., Hyndman, R., Newnham, G., and Culvenor, D.: Detecting trend and seasonal changes in satellite image time series, Remote Sens. Environ., 114, 106-115, 2010.

Verbesselt, J., Zeileis, A., and Herold, M.: Near real-time disturbance detection using satellite image time series, Remote Sens. Environ., 123, 98-108, 2012.

Vogl, A. and Lopes, V.: Evaluating Watershed Experiments through Recursive Residual Analysis, J. Irrig. Drain. Eng., 136, 348-353, 2010.

Watson, F. G. R., Vertessy, R. A., and Grayson, R. B.: Large-scale modelling of forest hydrological processes and their long-term effect on water yield, Hydrol. Process., 13, 689-700, 1999.

Webb, A. A., Kathuria, A., and Turner, L.: Longer-term changes in streamflow following logging and mixed species eucalypt forest regeneration: The Karuah experiment, J. Hydrol., 464-465, 412$422,2012$.
Wicht, C.: The validity of conclusions from South African multiple watershed experiments, in: International Symposium on Forest Hydrology, Pergamon Press, New York, NY, 749-758, 1967.

Williams, T. M., Amatya, D. M., Jayakaran, A. D., Song, B., Trettin, C. C., and Krauss, K.: Runoff generation from shallow southeastern forests: Unusual behavior of paired watersheds following a major disturbance, in: Proceedings of the Annual International Meeting, Paper number 121337045, 2012.

Wilson, L., Amatya, D., Callahan, T., and Trettin, C.: Hurricane impact on stream flow and nutrient exports for a first-order forested watershed of the lower coastal plain, South Carolina, in: Proceedings of the Second Interagency Conference on Research in the Watersheds, 16-18, Coweeta Hydrologic Laboratory Otto, NC, USA, 2006.

Young, C. E. and Klawitter, R. A.: Hydrology of wetland forest watersheds, in: Proceedings of CUCOH Hydrology Conference, 29-38, Clemson University, SC, 1968.

Young, C. E., Klawitter, R. A., and Henderson, J. E.: Hydrologic model of a wetland forest, J. Soil Water Conserv., 27, 122-124, 1972.

Zeileis, A., Leisch, F., Hornik, K., and Zeileis, M. A.: Package strucchange, Tech. rep., 2012.

Zon, R.: Forests and Water in Light of Scientific Investigation. Senate Document 469, in: 62nd Congress, US Government Printing Office, Washington, 1927. 